\title{
Measuring the Mediating Role of Entrepreneurial Orientation on the Relationship between Affective Organizational Commitment and Organizational Responsiveness: A Study of Egyptian Incubated Startups in ICT Sector
}

\author{
Marwa Tarek Abdel Azeem \\ College of Management and Technology, Arab Academy for \\ science, Technology and maritime transport, Cairo, Egypt \\ marwatarek@aast.edu
}

\begin{abstract}
Entrepreneurial Orientation (EO) encompasses and connects a vast range of management discipline which turns it to be a wide-spread concept. Based on Miller's theory, three dimensions of EO have been identified and used consistently: risk taking; innovativeness; and pro-activeness. Therefore, the main aim of this study is to measure the impact of EO on the relationship between affective organizational commitment and organizational responsiveness through the moderating effect of business incubator (BI). Based on the theoretical researches and data extracted from 185 entrepreneurs who are incubated by TIEC- one of the affiliates of ministry of Communication and Information Technology in Egypt, three hypothesized relationships are investigated in this study; the relationship between affective organizational commitment and EO, the relationship between $\mathrm{EO}$ and organizational responsiveness, and the moderating role of $\mathrm{BI}$ on the relationship between EO and organizational responsiveness. The results reveal that the affective committed employees have a significant impact on
\end{abstract}


EO dimensions since they regard the entrepreneurships positively and agree with their missions and goals. Such committed employees actively endorse what the entrepreneurship is doing and remain employed there because they want to. Also, EO has more significant influence on the organizational responsiveness in the presence of $\mathrm{BI}$ as the latter has played a vital role in speeding up the growth of start-ups and guiding early-stage businesses on the road to commercial success. However, BIs need to overcome many pitfalls: they need to provide real value in terms of supporting innovativeness and proactiveness, not just offering space and technological support, to measure success and progress more than just funding and to update their service portfolio especially for the elder generations and finally introducing more proper exit policies.

\section{Keywords:}

Affective Organizational Commitment, Miller's theory, Entrepreneurial Orientation, Risk Taking, Innovativeness, Proactiveness, Business Incubator, Organizational Responsiveness, Startups, Egyptian ICT.

\section{Introduction}

The phenomenon of an entrepreneurial orientation (EO) is considered as a driving force behind the organizational pursuit of entrepreneurial activities. Because of its importance, it became one of the dominant focuses in the entrepreneurship literature for many years of research (Covin and Wales, 2012).

The interest in EO can be traced to the pioneering and initial writings of Miller (1983) who introduced such concept to the scholarly literature. "Entrepreneurial Orientation" (EO) is used to refer to the organization's strategy-making process in entrepreneurial activities with three qualities - innovativeness, risk taking and proactiveness. (Lumpkin and Dess, 2001). Accordingly, EO is considered as a significant factor for a firm's 
success (Wang, 2008) especially in the dynamic business environment, in which businesses need to seek out new opportunities and efficiently exploit them. (Zhou et al., 2007).

Hence, the main purpose of this study is to measure the effect of EO and its dimensions - collectively and/or individually - on the relationship between affective commitment and organizational responsiveness as a key determinant of startup's superior performance, specifically in the presence of the moderating effect of the business incubator.

The application of the study is on the startups in one of the most significant sectors in Egypt, ICT sector. Such startups are financed and supported by Technology Innovation and Entrepreneurship Center (TIEC) which is one of the affiliate organizations of Egyptian Ministry of Communications and Information Technology (MCIT). It aims to make a new culture of business using technology and to drive entrepreneurship awareness in the ICT field for the benefit of national economy.

\section{Research Objectives}

The main research objective is to provide a critical indications for the relationship between affective organizational commitment and organizational responsiveness of the startups through the moderating effect of entrepreneurial orientation with its dimensions; Innovativeness, Risk-taking and Proactiveness in the presence of the business incubator. Such main objective can be divided into the following sub-objectives:

2.1 Investigating the relationship between affective organizational commitment and entrepreneurial orientation collectively and individually through its three dimensions; innovativeness, risk-taking and proactiveness.

2.2 Investigating the relationship between Entrepreneurial orientation dimensions and the organizational 
responsiveness in the presence of the moderating effect of business incubator.

\section{Theoretical Background}

\subsection{Affective Organizational Commitment}

According to Allen \& Meyer (1990), there are three components of organizational commitment: affective, continuance and normative commitment. Affective commitment is the most widely accepted concept compared to the other components (Hakimian, et al., 2016). It is defined as emotional attachment of the individuals with their organization, which means the employees are affectionately attached to the organizations and they want to stay and involve in the organization (Xerri and Brunetto, 2013). The authors proposed that affective commitment is based on desire; it's essentially staying for the affection of the job and what the organization represents. The commitment is considered affective when individuals are enjoying membership in the organization" (Allen and Meyer, 1990: 2). It refers to how much employees want to stay at their organization. If employees are affectively committed to their organizations, they will be satisfied with their work, feeling valued that they fit into the organization as they are considered the great assets of it (Werf, 2016). Rhoades et al. (2001) illustrated that having a sense of belonging and identification through the affective commitment is considered as an important element of loyalty and dedication. Consequently it increases the employees' involvement in the organization's activities, their willingness to achieve the organizational goals and their desire to remain with the organization. Affective commitment is directly related to positive work experience.

\subsection{Entrepreneurial Orientation}

Several studies have found that Entrepreneurial Orientation (EO) has become a central concept in the domain of 
entrepreneurship which has received a considerable amount of academic attention because of its significance in entrepreneurial decisions and actions. (Covin et al., 2006; Green et al., 2008; Tang et al., 2007; Wang, 2008; Lumpkin and Dess, 2001). According to Pelham (2000), the performance of small and medium-Sized firms depends primarily on both; internal factors (i.e., coordination, formalization, etc.) as well as on external factors (i.e., competitiveness, industry growth, market concentration, etc.). EO is one of the internal factors which has an impact on firm performance. As a strategic orientation, EO enhances overall variance in a firm's performance. Increased variance in performance can take place because many entrepreneurial actions may fail to generate an economic return thereby contributing to increased outcomes of firm's performance. The most widely used definition of EO is based on Miller's work (1983) and developed further by (Casillas et al., 2009; Hansen et al., 2011, and Runyan et al., 2012). They argued that EO Construct is considered as a multidimensional concept embraces three dimensions, which act individually, or collectively; risk-taking, innovativeness and pro-activeness.

\subsubsection{Innovativeness}

Innovativeness refers to a readiness to support creativity and experimentation as bases for developing new opportunities (Lumpkin and Dess, 2001). Moreover, Innovativeness is the ability of entrepreneur to implement or adapt new ideas, create new markets and introduce new products and services (Cromie, 2000; Gupta et al. 2004; Chen, 2007). Research findings have provided evidence that innovation is one of the key motives in starting a new business and also has a significant impact on its performance. In other words, innovativeness can stimulate people to pursue an entrepreneurial career and acting as a motivator, along with enabling them to have better performance 
and acting as a facilitator. (Shane, et al., 1991; Hisrich et al. $\underline{2008}$ ). Hence, many authors argue that successful entrepreneurs have more innovative features than non-entrepreneurs or unsuccessful ones (Koh, 1996; Ames and Runco, 2005; Gürol and Atsan 2006).

\subsubsection{Risk-taking}

Risk taking is a significant dimension of entrepreneurial orientation. It involves taking bold actions by undertaking the uncertainty with highly unpredictable outcome (Anlesinya et al., 2015) such as entering unknown new markets and committing a large portion of resources to new opportunities (Lumpkin and Dess, 2001). As EO is a strategic attitude, risk taking should be part of it. However, researchers are not able to find a consistent pattern between risk taking and entrepreneurship. Naldi, et al., (2007) stated that organizational structure and context in which the organization operates influence the amount of risk it takes.

\subsubsection{Proactiveness}

Many studies revealed that high proactive individuals have higher entrepreneurial intentions to act in anticipation of future demand and shape the environment (Crant, 1996; Lumpkin and Dess, 2001; Vantilborgh et al, 2015; Delle and Amadu, 2015). Therefore, in entrepreneurship, taking an advantage of new markets and opportunities is associated with proactiveness (Lumpkin and Dess, 1996). Moreover, a recent meta-analytic study established proactiveness as an important predictor of startups success (Rauch and Frese, 2007) through the strategy chosen by the entrepreneur. For instance, proactive entrepreneurs used to apply a prospector strategy, in order to recognize the new business opportunities through scanning the environment and focusing more on product development and market research (Kickul and Gundry, 2002).

\subsection{Organizational Responsiveness}


Organizational responsiveness is one of the basic factors for success of any business which is related to strategy and marketing that runs throughout numerous variables in management actions. So, it requires understanding and reacting rapidly to changes occur in its external and internal environment. Consequently, organizations are required to create more dynamic internal environment through both; culture and information which are considered as main determinants of organizational responsiveness to customers and competitors (Narver and Slater, 1990; Kohli and Jaworski, 1990; Homburg et al., 2007; Möller et al., 2009). Hence, organizational responsiveness is enhanced through exchanging knowledge, ideas, and thoughts related to business sustainability, and growth in order to be able to innovate, seize business opportunities and act proactively (Hult,et al., 2005; Pishdad and Haider, 2013). Zajac et al.,(2000) and Verdu and Gomez-Gras (2009) suggested that organizational responsiveness is based on the concept of organizational flexibility as the latter is one of the main dynamic capabilities that supports company to face any fluctuations. It makes it more responsive to changes without incurring high reorganization cost, time or effort, as all companies can change easily in the absence of such limitations (Helo, 2004).

\section{Hypotheses development}

\subsection{Affective Organizational Commitment and Entrepreneurial Orientation}

Generally, affective commitment is directly related to positive work experience and conditions. So, Karam, (2017) argued that affective commitment is considered as a predictor of employee absenteeism, performance, and turnover, as well as other behaviors. Moreover, affective commitment has been linked to important employee outcomes in terms of reducing withdrawal 
behaviors, as well as increased likelihood to engage in extra tasks that benefit the entrepreneurship as a whole and may grant it a competitive advantage in the market. Also, as proposed by Karam, (2017) affective commitment plays an important role in organizational outcomes of the entrepreneurships in terms of better job involvement and job satisfaction. De Clercq et al. (2009) find that organizational commitment moderates the relationship between EO and entrepreneurial performance.

Hence, the relationship is strengthened when commitment is high and is weakened when the commitment is low. They argued that the reason behind the strong relationship is the quality and the quantity of knowledge that can be disseminated by highly committed staff which leverage the entrepreneurship's ability to exploit entrepreneurial opportunities. Based on the previous literature, the following hypothesis can be drawn as:

H1: Affective organizational commitment has a significant influence on Entrepreneurial Orientation

\subsubsection{Affective Organizational Commitment and Innovativeness}

In order to achieve a high level of innovativeness, companies need to possess the following features: strong clearly expressed shared values; cultures that encourage openness and playfulness and a strong, clearly communicated sense of history. All of these features need more stable entrepreneurship with high level of affective commitment of its workforce (Zannad and Rouet, 2003). To emphasize, a survey conducted by one of the career innovation companies on one thousand young

professionals worldwide. It found that employers always strive when managing young talents. As well, many established companies are not encouraging the innovativeness in contrast to 
the startups. Start-ups are considered exciting places for talented young people who learn rapidly and make a personal influence in their jobs which comes from their sense of personal ownership and their affective commitment. As well, this survey shows that the attraction to innovate in the startups' staff has not diminished despite the downturn in the market as they have the desire to stay in their jobs and enjoy their membership there (Zannad and Rouet, 2003).

Employees who are emotionally attached to their organizations are more likely to share knowledge and bring innovative ideas (Thompson and Heron, 2006) as they enhance their state of minds towards organizational advancement and steps forward the organizational development Chughtai (2013). Moreover, the affective commitment reduces the employees' turnover which minimizes the interruption occurs in the organizational innovation process and affects positively on the innovativeness. Moreover, a productive and positive interaction among the employees may enhance the commitment which in turn results in better innovative output (Liu et al., 2011). Therefore, the following hypothesis can be postulated:

Hla: Affective organizational commitment has a significant influence on innovativeness

\subsubsection{Affective Organizational Commitment and Risk- taking}

Although the employees prefer a stable exchange relationship to a temporary one, mainly to reduce uncertainties, entrepreneurship has a different risky nature which is supported by the affective commitment. Such commitment is the bond between the employee and the organization which gradually grows into long-term successful exchanges and enhances their desire to enjoy the membership in their jobs (Liu and Wang, 
2013). In other words, an entrepreneur has some characteristics and traits that differentiate him/her from a non-entrepreneur.

Entrepreneurs are persons who are ready to involve in dynamic and persistent efforts to convert their ideas into profitable and operating companies (Baron, 2007). They have certain skills and abilities that are most closely to the activities they perform in launching, developing, and operating new ventures in their entrepreneurship (Shane, et al., 2003, Landy and Conte, 2006). The role of employee commitment with organization is very vital in risk taking characteristic within the entrepreneurship. Employees' participation or contribution is vital for risk management as the affective commitment contributes to employee's participation in risky behavior process and perceived effective enterprise risk management. Actually, higher affective commitment may lead to better employees' participation who are indirectly motivated with their own desire to contribute meaningfully to the organization due to the sense of obligation that they had towards the organization success (Gellatly et al., 2006). Consequently, the following hypothesis can be concluded;

H1b: Affective organizational commitment has a significant influence on risk-taking.

\subsubsection{Affective Organizational Commitment and Proactiveness}

Den Hartog and Belschak, (2007), emphasized that employees who are affectively committed feel responsible to convey this commitment into specific targets and goals through their personal initiative. This means that they possess the ability to fulfill these targets and return goodness. Sonnentag (2003) found a significant relationship between persistent, positive and affective motivational state of fulfillment from one side and 
proactive behavior from the other side. Also, confirmed on the same meaning, people with high affective commitment and feel a strong bond with the organization, have high proactive personality which tend to be relatively unconstrained by situational forces and have a great effect on changing the environment. They have the ability of identifying opportunities and show initiative to create meaningful changes in the environment proactively (Gudermann, 2010). Hence, the following hypothesis can be proposed:

H1c: Affective organizational commitment has a significant influence on proactiveness.

\subsection{Entrepreneurial Orientation and Organizational Responsiveness}

Entrepreneurships must proactively adjust their internal structures (e.g. technical, political and cultural) to cope with the environmental change and accordingly increase its market responsiveness. It indicates to the organization ability to respond rapidly to changing market demands (Garrett et al., 2009).

Moreover, Rauch et al. (2009) conducted a meta-analysis of the relationship between EO and entrepreneurship success. Their survey was conducted on a number of entrepreneurships from different aspects. It showed a significant positive relationship between EO and entrepreneurship success and responsiveness. In other words, the results clearly show that businesses are likely to benefit more from pursuing an EO with its dimensions. Also, EO may be viewed as the entrepreneurial strategy-making processes which enacts the entrepreneurial organizational purpose and sustain its competitive advantage(s). Based on the previous studies, the following hypothesis can be drawn as:

H2: Entrepreneurial Orientation in startups has a significant influence on Organizational Responsiveness. 


\subsubsection{Innovativeness and Organizational Responsiveness}

Responsiveness needs to gain superior knowledge about customers, markets, competitors and many other factors that contribute in optimizing utilization of opportunities and being more flexible to threats. This knowledge is then incorporated with the daily business processes to increase the effectiveness and efficiency of business's operations (Cegarra-Navarro and Martinez-Conesa, 2007; Ng et al., 2012).

Accordingly, rapid responsiveness leads to attain goals quicker, cheaper and at higher quality than their competitors and in turn, help in achieving a sustainable competitive advantage (Gebert et al., 2002). Rubera and Kirca (2012:132) proposed that "Innovativeness has direct positive effects on financial position and firm value and that innovation is increasingly seen as the

key to unlocking competitive advantage, as much for countries as for companies". From this perspective, innovativeness may be regarded as a driver for achieving a sustainable competitive advantage through assisting the company to be more responsive (Soliman, 2013).

The argument is that developing right innovations which employs the firm's capabilities, resources and processes could assist in guiding the firm's decisions towards how to better manage its resources especially intangibles and know-how to meet the firm's objectives. In other words, innovativeness could therefore deliver an added-value and build a sustainable competitive advantage (Soliman, 2013). Innovativeness has a key role in the company's response to changes in the environment, with positive effects on its performance. For example, combining and disseminating potentially complementary components of knowledge is critical for successful innovation which contributes in being more 
responsive. In addition, it is suggested that innovative ways to integrate knowledge components is considered as a crucial element in the generation of innovative products and technologies (Leiponen and Helfat, 2003) which in turn, affects positively on the responsiveness.

In sum, it is hypothesized the following:

H2a: Innovativeness in startups has a significant influence on organizational responsiveness.

\subsubsection{Risk-Taking and Organizational Responsiveness}

In the current environment of business, risks that can arise may be unexpected, with no base of evidence or of experience to draw upon in determining their occurrence (Ekstein, 2007). For that reason, the capability and readiness of risk responsiveness became so critical issue in entrepreneurships. Risk responsiveness is the process of developing strategic decisions, and determining actions, to utilize business opportunities and reduce the threats of risks faced by entrepreneurships. It may include the assignment of certain persons to take the responsibility of such process,

address the risks by their priority, assign resources and allocate activities into the budget. Because of its risky nature, entrepreneurship should be more responsive through a realistic plan within the entrepreneurship context and appropriate to the significance of the risk and cost effective in facing such risk (PMBOK Guide, 2008).

In sum, the greater the perceived threat from risk, the more motivated an entrepreneurship will be to respond rapidly to risk and in turn to reduce the threat (Chess, 1999). Therefore, the following hypothesis is explored as follows: 
H2b: Risk- taking in startups has a significant influence on organizational responsiveness.

\subsubsection{Proactiveness and Organizational Responsiveness}

Through pro-activeness, entrepreneurship is simply highly energized in understanding and satisfying the potential customers' needs. Hence to be responsive, it is essential to uncover these latent needs and to develop creative solutions to satisfy these needs. (Lamore et al., 2013). Moreover, proactive companies perform better than competitors because they respond rapidly to the market changes (Hughes and Morgan, 2007), respond to the actions of competitors (Felício et al., 2012) and become leaders in their industries with opportunities they found before their competitors (Lumpkin and Dess, 1996).

Furthermore, Oni (2012) argued that sustainable competitive advantage that a particular entrepreneurship has over its competitors depends on the degree to which its proactiveness is controlled and its ability to respond promptly to any changing environmental trends. Companies can respond positively to changes through establishing a unit that reviews and monitors its entrepreneurial policy concerning innovativeness, awareness, calculated risk and potential opportunities and strategies to improve performance. These companies can be categorized as high entrepreneurial proactive. Therefore, the following hypothesis is suggested;

H2c: Proactiveness in startups has a significant influence on organizational responsiveness

\subsection{The Moderating Effect of Business Incubator}

According to Ackah (2011); Southiseng and Walsh (2010), entrepreneurs confront many difficulties in their struggle to keep the business in place. Mainly, they suffer from limited financial 
sources, in addition to lack of technical support. Also, they suffer from several administrative and official procedures burden, technological obstacles, poor infrastructure and lack of skills and management techniques. For that reason, Business Incubators are found to assist new entrepreneurs with business start-up to overcome such obstacles through providing them with various services such as, access infrastructure, marketing, financial aid and technical support. Generally business incubators can be viewed as "... a support environment for startup and fledgling companies" (Peters et al., 2004: 83). In more depth, they may viewed as "...programs designed to accelerate the successful development of entrepreneurial companies through an array of business support resources and services, developed and managed by incubator management and offered both in the incubator and through its network of contacts" ( Lesáková, 2012:85). Moreover, Research on entrepreneurial orientation (EO) has investigated its positive consequences including the business incubator's nature to empower employees to engage themselves in their proactive actions as a response of market forces (Luu, 2017; Lechner and Gudmundsson, 2014).

In fact, business incubators are considered worldwide as a crucial means for the progress of startups and principal tool for substantial resources which are invested in them (Lose \& Tengeh, 2015). The duration a company spends in an incubation program relies heavily on many elements, including the type of business and the entrepreneur's level of business expertise. For example, entrepreneurs which need more focus on $R \& D$ cycles require more time in an incubation program than manufacturing or service ones which can immediately produce and bring to market a product or service. Incubators vary in the way they deliver their services and in the types of clients they serve. 
Classical incubators are responsible for giving support in

starting the business through direct financial funding, recommendations, lease of space, constructing the administrative infrastructure and many other services. Technological incubators support entrepreneurs technologically typically as start-up and spin-off ones (Lesáková, 2012). In a number of more competitive economies, business incubation is one of the tools that assist in creating new entrepreneurial skills and new businesses. Then, business incubation can handle the business problems, deeply lowering the usual early stage failure rate and supports them through organizing workshops with interested relevant entities to provide them with required training programs and exchange experiences about successful business incubators. The incubation process was developed to support start up business and be better able to survive in the competitive environment on a longer-term sustainable basis. It targets small entrepreneurships who want to grow, and who would like to develop their talent and ideas and commercialize them (Bayhan, 2006). However, business incubators have to ensure sufficient resources to provide the required incubation facilities at the desired level and quality. Business incubators empower the entrepreneurships through sharing information, resources and power so that they can take initiative and make decisions to solve their own problems and improve service and performance. The idea behind the business incubators' empowerment is that granting the entrepreneurships the skills, resources, authority, opportunities, motivation, as well making them more responsible and accountable for their outcomes, will contribute to their competence and improve their abilities as a first step in their business lives. 
They create value to the entrepreneurships by providing them with the required support such as facilitation services to assist them in developing sustainable businesses (Tötterman and Sten, 2005; Hughes et al., 2007). Generally, most of the studies and researches show that business incubators importance is derived from sharing the following resources (Hsu et al., 2003; Lyons and Li, 2003; Nolan, 2003; Collinson and Gregson,

2003; Aernoudt, 2004; Hackett and Dilts, 2004a; Peters et al., 2004; Bollingtoft and Ulhoi, 2005; Chan and Lau, 2005; Abduh et al., 2007; Bergek and Norrman, 2008; Somsuk and Laosirihongthong, 2014):

- Human resources: which are composed by incubator's management team and staff including knowledge, experience and professional business support or advice ("coaching");

- Technology resources: which are products and technology e.g., laboratories, technology capabilities, technical skills and network provision;

- Financial resources: in terms of financial support; and

- Organizational resources: make reference to planning, coordinating, monitoring, routines and relationships related to an organization.

Therefore, according to these studies and researches the following hypothesis can be suggested:

H3: Business incubator moderates the relationship between entrepreneurial orientation and organizational responsiveness. II 


\section{Proposed Research Framework}

In accordance with the literature review, our proposed research framework is developed as at figure (1) below:

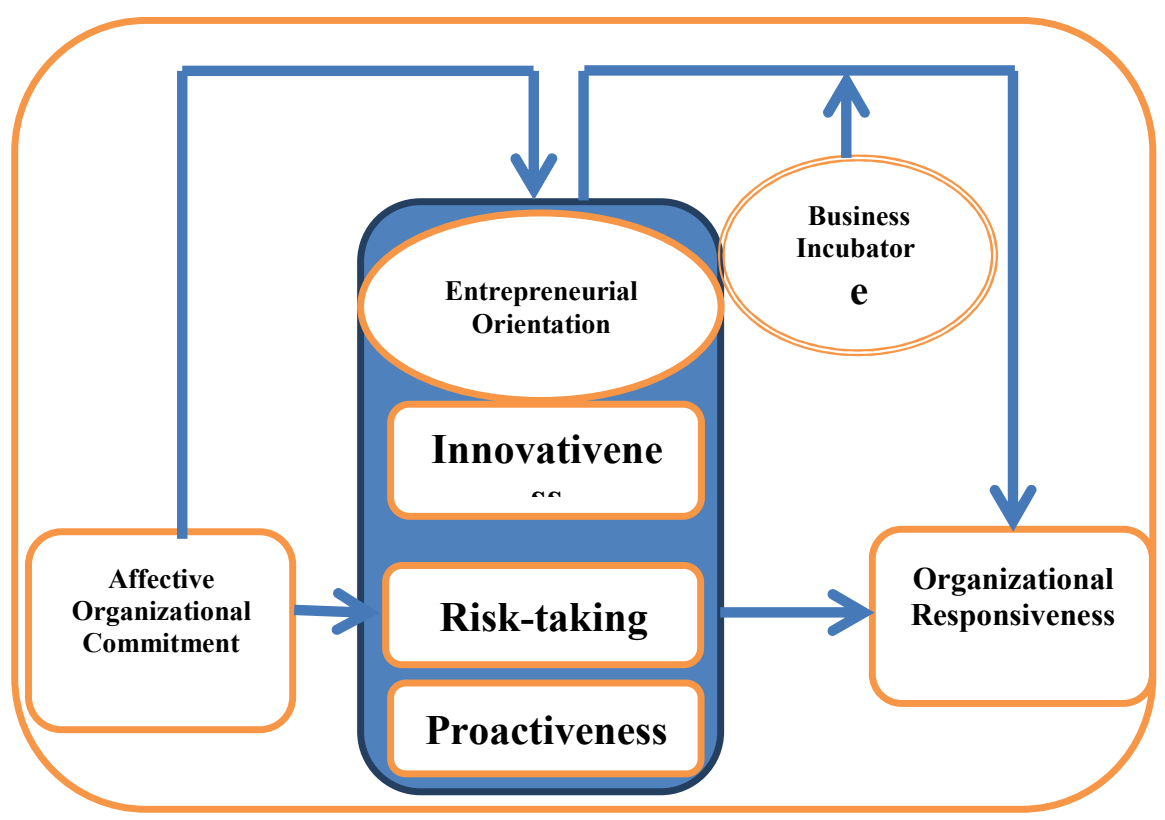

Figure (1): Proposed Research framework

The evidences from the literature review were the bases on which the proposed research framework is grounded. It proposes that affective organizational commitment affects significantly the entrepreneurial orientation collectively and individually through its main determinants; innovativeness, risktaking and proactiveness - as depicted in figure (1).

Moreover, depending on the literature, we argue that each determinant of entrepreneurial orientation is supposed to have a significant impact on organizational responsiveness which influence ultimately on providing customers with superior 
value emphasizing on the start-up's capabilities in developing and deploying the available resources in a way that match the current turbulent environment. In the proposed model, business incubator is applied as a moderator because of its significant role in changing the effect of entrepreneurial orientation on organizational responsiveness.

\section{Methodology and Sampling}

\subsection{Sampling plan}

\subsubsection{Target population}

The population of this study consists of the startups in Communications and Information Technology sector in Egypt. Startups are selected as the empirical context of this research because they are the primary driver for job creation and economic growth. They play a major role in most economies, particularly in developing countries. According to World Bank estimates, 600 million jobs will be needed in the next 15 years to absorb the growing global workforce essentially in Sub-Saharan Africa (World Bank, 2015).

\subsubsection{Sampling frame}

The sampling frame is the group from which the researcher selects the sample. Here, the sampling frame is all of the startups incubated by ministry of Communications and Information Technology through "Technology Innovation and Entrepreneurship Center (TIEC) ${ }^{1}$. Startups in TIEC are categorized as follows; 128 newly startups established as a result of participating in TIEC's programs as well as graduated startups and currently incubated ones. Also, there are 318 startups that received any kind of support (financial/ in-kind)

1 - One of the affiliate organizations of Ministry of Communications and Information Technology (MCIT) in Egypt. It aims to drive innovation and entrepreneurship in ICT for the benefit of national economy. It seeks to become the leading Regional Hub and world class center for ICT based innovations and entrepreneurship. For more details: http://www.tiec.gov.eg/en-US/Accelerator/Pages/About.aspx 
through one of TIEC programs. Hence, the sampling frame includes 446 startups that cover two governorates; Cairo and Asuit where TIEC operates and incubates startups in Egypt (TIEC, 2017).

\subsubsection{The unit of analysis}

The unit of analysis selected for this study is the organizational level particularly the owners or top managers of the startups incubated by TIEC which offers a fully fledge incubation package to startups in the ICT sector. Owners or top management are the key informants to provide the information required.

\subsubsection{The sample size}

According to statistical data retrieved for TIEC in Cairo and Asuit, the total number of startups is $\underline{\mathbf{4 4 6}}$. So, the sample size is 206 as calculated by the following formula (Berenson et al., 2013):

$\mathrm{n}^{\prime}=Z_{\frac{\alpha}{2}} \mathrm{p}(1-\mathrm{p}) / \mathrm{e}^{2}$

\section{where:}

$\mathrm{Z} \alpha / 2$ is the critical value of the Normal distribution at $\alpha / 2$ (e.g. for a confidence level of $95 \%, \alpha$ is 0.05 and the critical value is 1.96)

e is the margin of error and it is approximated to be 0.1

$\mathrm{p}$ is the sample proportion $(50 \%)$.

$\mathrm{N}$ is the population size and equal to 446.

So, $\mathrm{n}^{\prime}=1.69(0.5)(1-0.5) / 0.12=384$

Then, we use the following formula using correction factor:

$\mathrm{n}=\frac{\mathrm{Nn} \prime}{\mathrm{n}^{\prime}+(\mathrm{N}-1)}$

$\mathrm{n}=\frac{384 * 446}{384+(446-1)}=206$ 


\subsubsection{Data Sources}

With regard to the impact of the entrepreneurial orientation on the relationship between affective organizational commitment and the organizational responsiveness, data has been sourced mainly from the interviews conducted with the startups managers and/or owners. Moreover, the study data has been sourced from various authentic sources; academic journals, Ministry of Communications and Information Technology in Egypt website, Business Incubator (TIEC) website, international associations, and through access to some paid databases.

\subsection{Research Methods Used}

The research method used is "inductive reasoning" which works from specific observations (the conclusion of startups funded by one of the business incubators (TIEC) to broader generalizations (startups in Egypt). An analytical plan is designed to process the data for information and empiricallybased insights. The analytical techniques that used in this research are; Confirmatory Factor Analysis, Correlation Analysis, Simple Regression Analysis and SEM (AMOS).

\subsection{Data Collection and Analysis Method}

\subsubsection{A Pilot Study}

A total of 2 managers from TIEC and 12 managers of startups under study are invited to participate in the pre-test during which they were asked by using open-ended questions through short interview which lasted for about 15-20 minutes each. During conducting these interviews an initial feedback is collected from them. They are asked to find out any difficult expression or unclear statement included in the questionnaire. Then, the questionnaire revised and updated to be ready for the distribution on the potential participants after being more acceptable and satisfactory. 


\subsubsection{Interviews}

A list of standardized and open-ended questions with interviewing guide is used as a tool to collect data in the interviews conducted in startups funded by the business incubator; (TIEC). The key informants in these interviews are the startups top managers/owners in order to provide more accurate information. Such methodology can capture a large volume of information, allows for clarification, helps in getting more organized data and facilitating faster interviews that can be more easily analyzed and compared (Marshall and Rossman, 1999).

\subsubsection{Questionnaire Design}

To address the research objectives, closed-ended questionnaires* are distributed to the sample of startups, hand to hand or via e-mails. It is 31 -item questionnaire which is designed based on the proposed research framework and the developed hypotheses. The questionnaire represents 3 sections; the first one covers 26 questions divided into the following categories; 6 questions related to affective commitment, 12 questions cover 3 dimensions of entrepreneurial orientation; (risk-taking, innovativeness and pro-activeness respectively), 4 questions about the performance of the business incubator; TIEC and finally $\mathbf{4}$ questions concerning the organizational responsiveness. then, the second section contains only $\mathbf{2}$ questions concerning respondents' demographics. Lastly, third section contains 3 general questions of the startups business nature.

The questions were translated and distributed to the managers of the startups who were asked to indicate the degree 
to which they agree with the statements of the previous sections. All statements are measured using a Likert scale, 5-point scale of agreement; $1=$ "Strongly disagree" to 5= "Strongly agree". 206 questionnaires are distributed, 21 questionnaires are excluded from analysis to avoid non-response or skewed answers** $^{*}$ and a final sample of 185 questionnaires was finally drawn.

\section{Statistical analysis}

The aim of this report is to answer the hypotheses of this research, which are:

H1: Affective organizational commitment has a significant influence on Entrepreneurial orientation

Hla: Affective organizational commitment has a significant influence on innovativeness

H1b: Affective organizational commitment has a significant influence on risk-taking.

H1c: Affective organizational commitment has a significant influence on proactiveness.

H2: Entrepreneurial orientation in startups has a significant influence on organizational responsiveness

H2a: Innovativeness in startups has a significant influence on organizational responsiveness.

H2b: Risk- taking in startups has a significant influence on organizational responsiveness.

H2c: Pro-activeness in startups has a significant influence on organizational responsiveness.

** After reviewing the received questionnaires, some of them are avoided which contain completely skewed answers either towards strongly agree or strongly disagree in addition to the unanswered ones. 
H3: Business incubator moderates the relationship between entrepreneurial orientation and organizational responsiveness.

\subsection{Data Analysis Techniques}

Building indicators: the indicators are composed by using equal weights method. Each indicator is calculated by adding the scores of questions which are related to this indicator, and then this sum is divided by the number of related questions. These created indicators are used in answering the research hypotheses. The created indicators are:

- Affective organizational commitment

- Entrepreneurial orientation

- Innovativeness

- Risk-taking

- Pro-activeness

- Business incubator

- Organizational responsiveness

Alpha- Cronbach: it is used to determine the extent of the scale reliability and self-validity. For reliability of the variables, Cronbach's Alpha test is used to evaluate the stability of the questionnaire and reliability of the measures. Cronbach's alpha takes values between 0 and 1 . The nearer the Cronbach's alpha to 1 , the better the stability of the questionnaire is. More precisely, we can say that the questionnaire is stable if Cronbach's alpha is greater than 0.5 .

Confirmatory Factor Analysis: explores the interrelationships among variables to discover if those variables can be grouped into a smaller set of underlying factors. Factor Analysis is used to test the construct validity.

Correlation Analysis: correlation analysis aims to know the direction and the strength of the relation between two variables. When the coefficient is positive, the relation is a direct one and when it is negative, it means that there is an inverse relationship. 
It takes values between -1 and 1 . The relationship is weak if absolute value of coefficient between 0 and 0.3 and moderate if it is between 0.3 and 0.6 and strong if it is higher than 0.6. We decide if there is a significant relationship at $95 \%$ confident or not if the $\mathrm{p}$-value is less than 0.05 .

Simple Regression Analysis: it is used to examine the relationship between affective organizational commitment and the factors of Entrepreneurial orientation.

SEM (AMOS): analysis of a Moment Structures as a technique of the Structural Equation Modeling is used to estimate the conceptual framework relationships.

\subsection{Reliability and Intrinsic Validity of Research Constructs}

In this subsection the results of both Cronbach's alpha to measure reliability and average inter-item correlation to measure intrinsic validity are presented. The following table presents the result of Cronbach's alpha measure and average inter-item correlation. 
Table (1) Reliability and Intrinsic Validity of Research Constructs

\begin{tabular}{|cl|l|l|l|}
\hline Item & $\begin{array}{l}\text { Number of } \\
\text { Questions }\end{array}$ & $\begin{array}{l}\text { Reliability } \\
\text { measure }\end{array}$ & $\begin{array}{l}\text { Intrinsic } \\
\text { validity }\end{array}$ \\
\hline$\bullet \begin{array}{l}\text { Affective } \\
\text { organizational } \\
\text { commitment }\end{array}$ & 6 & 0.531 & 0.569 \\
\hline $\begin{array}{l}\text { Entrepreneurial } \\
\text { orientation }\end{array}$ & $\begin{array}{l}\text { Average of } \\
\text { f factors }\end{array}$ & 0.577 & 0.822 \\
\hline$\bullet$ & Innovativeness & 4 & 0.641 & 0.572 \\
\hline$\bullet$ & Risk-taking & 4 & 0.583 & 0.562 \\
\hline$\bullet \quad$ Pro-activeness & 4 & 0.531 & 0.544 \\
\hline$\bullet$ & Business incubator & 4 & 0.549 & 0.584 \\
\hline$\bullet \quad \begin{array}{l}\text { Organizational } \\
\text { responsiveness }\end{array}$ & 4 & 0.546 & 0.572 \\
\hline
\end{tabular}

Table (1) illustrates that the survey is reliable as the Cronbach's alpha and average inter-item correlation coefficient for all of the items are greater than 0.5 . 
7.3. Confirmatory factor analysis to measure validity of research constructs

Table (2) Confirmatory Factor Analysis (CFA) of Research Constructs

\begin{tabular}{|c|c|c|c|c|c|c|c|}
\hline & $\begin{array}{l}\text { Affective } \\
\text { org. } \\
\text { commitment }\end{array}$ & $\begin{array}{l}\text { Innova- } \\
\text { tivenes }\end{array}$ & $\begin{array}{l}\text { Risk- } \\
\text { taking }\end{array}$ & $\begin{array}{l}\text { Proact- } \\
\text { iveness }\end{array}$ & $\begin{array}{l}\text { Bus. } \\
\text { incubator } \\
\text { TIEC } \\
\end{array}$ & $\begin{array}{l}\text { Org. } \\
\text { Respon- } \\
\text { siveness }\end{array}$ & $\begin{array}{l}\text { Commun- } \\
\text { alities }\end{array}$ \\
\hline \multicolumn{8}{|l|}{$\begin{array}{l}\text { A. Affective } \\
\text { Organizational } \\
\text { Commitment }\end{array}$} \\
\hline $\begin{array}{l}\text { 1. I would be } \\
\text { very happy to } \\
\text { spend the rest of } \\
\text { my career in } \\
\text { this } \\
\text { organization }\end{array}$ & 0.511 & & & & & & 0.766 \\
\hline $\begin{array}{l}\text { 2. I really feel } \\
\text { as if this } \\
\text { organization's } \\
\text { problems are } \\
\text { my own. }\end{array}$ & 0.592 & & & & & & 0.479 \\
\hline $\begin{array}{l}\text { 3. I feel like } \\
\text { 'part of my } \\
\text { family' at this } \\
\text { org. }\end{array}$ & 0.748 & & & & & & 0.579 \\
\hline $\begin{array}{l}\text { 4. I feel } \\
\text { 'emotionally } \\
\text { attached' to this } \\
\text { org. }\end{array}$ & 0.664 & & & & & & 0.62 \\
\hline $\begin{array}{l}\text { 5. This } \\
\text { organization has } \\
\text { a great deal of } \\
\text { personal } \\
\text { meaning for me }\end{array}$ & 0.864 & & & & & & 0.755 \\
\hline $\begin{array}{l}\text { 6. I feel a strong } \\
\text { sense of belonging } \\
\text { to this org. }\end{array}$ & 0.825 & & & & & & 0.704 \\
\hline $\begin{array}{l}\text { B. } \\
\text { Entrepreneurial } \\
\text { Orientation }\end{array}$ & & & & & & & \\
\hline $\begin{array}{l}\text { B1. } \\
\text { Innovativeness }\end{array}$ & & & & & & & \\
\hline $\begin{array}{l}\text { 7.Our firm has a } \\
\text { strong emphasis } \\
\text { on R\&D, } \\
\text { leadership \& } \\
\text { innovation }\end{array}$ & & 0.950 & & & & & 0.903 \\
\hline
\end{tabular}


Measuring the Mediating Role

Dr. Marwa Tarek Abdel Azeem 1/8/2018

\begin{tabular}{|c|c|c|c|c|c|c|c|}
\hline & $\begin{array}{l}\text { Affective } \\
\text { org. } \\
\text { commitment }\end{array}$ & $\begin{array}{l}\text { Innova- } \\
\text { tivenes }\end{array}$ & $\begin{array}{l}\text { Risk- } \\
\text { taking }\end{array}$ & $\begin{array}{l}\text { Proact- } \\
\text { iveness }\end{array}$ & $\begin{array}{l}\text { Bus. } \\
\text { incubator } \\
\text { TIEC }\end{array}$ & $\begin{array}{l}\text { Org. } \\
\text { Respon- } \\
\text { siveness }\end{array}$ & $\begin{array}{l}\text { Commun- } \\
\text { alities }\end{array}$ \\
\hline $\begin{array}{l}\text { 8. Our firm has } \\
\text { many new lines of } \\
\text { products in the } \\
\text { past five years (or } \\
\text { since its } \\
\text { establishment). }\end{array}$ & & 0.577 & & & & & 0.542 \\
\hline $\begin{array}{l}\text { 9. Our changes in } \\
\text { product lines have } \\
\text { usually been quite } \\
\text { dramatic. }\end{array}$ & & 0.518 & & & & & 0.568 \\
\hline $\begin{array}{l}\text { 10. Our firm } \\
\text { engages } \\
\text { innovative } \\
\text { behaviors and } \\
\text { activities }\end{array}$ & & 0.958 & & & & & 0.918 \\
\hline \multicolumn{8}{|l|}{ B2. Risk-taking } \\
\hline $\begin{array}{l}\text { 11. Our firm has a } \\
\text { strong proclivity } \\
\text { for high-return } \\
\text { high-risk project }\end{array}$ & & & 0.752 & & & & 0.679 \\
\hline $\begin{array}{l}12 \text {. Our firm takes } \\
\text { bold and wide- } \\
\text { ranging acts to } \\
\text { achieve } \\
\text { objectives }\end{array}$ & & & 0.756 & & & & 0.709 \\
\hline $\begin{array}{l}13 . \text { Our firm } \\
\text { adopts a bold, } \\
\text { aggressive posture } \\
\text { to maximize } \\
\text { probability of } \\
\text { exploiting } \\
\text { potential } \\
\text { opportunities. }\end{array}$ & & & 0.764 & & & & 0.626 \\
\hline $\begin{array}{l}\text { 14. Our firm } \\
\text { encourages risk- } \\
\text { taking behaviors }\end{array}$ & & & 0.802 & & & & 0.671 \\
\hline \multicolumn{8}{|l|}{ B3. Proactiveness } \\
\hline $\begin{array}{l}15 . \text { Our firm } \\
\text { typically initiates } \\
\text { actions to which } \\
\text { competitors have } \\
\text { to respond to. }\end{array}$ & & & & 0.811 & & & 0.700 \\
\hline $\begin{array}{l}\text { 16. Our firm is } \\
\text { often the first to } \\
\text { introduce } \\
\text { products. }\end{array}$ & & & & 0.753 & & & 0.637 \\
\hline
\end{tabular}




\begin{tabular}{|c|c|c|c|c|c|c|c|}
\hline & $\begin{array}{l}\text { Affective } \\
\text { org. } \\
\text { commitment }\end{array}$ & $\begin{array}{l}\text { Innova- } \\
\text { tivenes }\end{array}$ & $\begin{array}{l}\text { Risk- } \\
\text { taking }\end{array}$ & $\begin{array}{l}\text { Proact- } \\
\text { iveness }\end{array}$ & $\begin{array}{l}\text { Bus. } \\
\text { incubato } \\
r \text { TIEC }\end{array}$ & $\begin{array}{l}\text { Org. } \\
\text { Respon- } \\
\text { siveness }\end{array}$ & $\begin{array}{l}\text { Commun- } \\
\text { alities }\end{array}$ \\
\hline $\begin{array}{lr}\text { 17. Our firm adopts } \\
\text { a } & \text { competitive } \\
\text { strategy } & \end{array}$ & & & & 0.814 & & & 0.698 \\
\hline $\begin{array}{l}\text { 18. Our firm } \\
\text { responds to } \\
\text { unrelated } \\
\text { opportunities }\end{array}$ & & & & 0.765 & & & 0.642 \\
\hline \multicolumn{8}{|l|}{$\begin{array}{l}\text { C. Business } \\
\text { Incubator }\end{array}$} \\
\hline $\begin{array}{l}\text { 19. TIEC helps us } \\
\text { in handling our } \\
\text { business problems }\end{array}$ & & & & & 0.932 & & 0.874 \\
\hline $\begin{array}{l}\text { 20. TIEC helps us } \\
\text { in deeply lowering } \\
\text { the usual early } \\
\text { stage failure rate }\end{array}$ & & & & & 0.818 & & 0.670 \\
\hline $\begin{array}{l}\text { 21. TIEC helps us } \\
\text { to be better able to } \\
\text { survive on a } \\
\text { longer-term basis }\end{array}$ & & & & & 0.545 & & 0.458 \\
\hline $\begin{array}{l}\text { 22. Generally, } \\
\text { TIEC supports us } \\
\text { to sustain our } \\
\text { competitive } \\
\text { advantage }\end{array}$ & & & & & 0.61 & & 0.478 \\
\hline \multicolumn{8}{|l|}{$\begin{array}{l}\text { D. Org } \\
\text { Responsiveness }\end{array}$} \\
\hline $\begin{array}{l}\text { 23. Our firm is } \\
\text { respond to market } \\
\text { changes in an } \\
\text { appropriate } \\
\text { manner }\end{array}$ & & & & & & 0.655 & 0.671 \\
\hline $\begin{array}{l}\text { 24. Our org. is } \\
\text { able to mitigate } \\
\text { negative threats }\end{array}$ & & & & & & 0.869 & 0.806 \\
\hline $\begin{array}{l}25 . \text { Our org. is } \\
\text { able to capitalize } \\
\text { on positive } \\
\text { opportunities }\end{array}$ & & & & & & 0.95 & 0.906 \\
\hline $\begin{array}{l}26 . \text { Our org. is } \\
\text { able to reconstruct } \\
\text { market boundaries }\end{array}$ & & & & & & 0.952 & 0.91 \\
\hline
\end{tabular}


All communalities values for all components are greater than 0.5 which indicate high validity of these items, whereas all values of loadings are greater than 0.5 indicates high correlation between these questions.

From all of the above it can be concluded that construct validity for the survey is acceptable. After presenting validity and reliability of the questionnaire, the following section presents descriptive statistics and the answers of the hypotheses.

\subsection{Respondents' Demographic Variables and Startups Information.}

7.4.1. Distribution of the sample members according to gender

Table (3) Descriptive Statistics for Respondents' Gender

\begin{tabular}{|l|l|l|l|}
\hline \multirow{3}{*}{ Valid } & Male & 141 & Percent \\
\cline { 2 - 4 } & Female & 44 & 76.2 \\
\cline { 2 - 4 } & Total & 185 & 23.8 \\
\hline & & 100.0 \\
\hline
\end{tabular}

From the above table it is concluded that $76.2 \%$ are males, while females represent $23.8 \%$ of the sample which emphasizes the fact that males still heavily outnumber females in the highrisk world of entrepreneurship and venture-capital backed startups.

7.4.2. Distribution of the sample members according to age Table (4) Descriptive Statistics for Respondents' Age

\begin{tabular}{|l|l|l|l|}
\hline \multirow{3}{*}{ Valid } & Frequency & Percent \\
\cline { 2 - 4 } & $20-$ less than 30 & 96 & 51.9 \\
\cline { 2 - 4 } & $30-$ less than 40 & 71 & 38.4 \\
\cline { 2 - 4 } & 40 and more & 18 & 9.7 \\
\cline { 2 - 4 } & Total & 185 & 100.0 \\
\hline
\end{tabular}


From the above table, it is clear that $51.9 \%$ of the sample aged from 20 to less than 30 , and $38.4 \%$ of the sample aged from 30 to less than 40 , while $9.7 \%$ aged more than 40 . It means that the majority of sample's respondents are in youth early stage. One possible way to justify that is the need to address the most critical problem in Egypt which is the high youth unemployment rate. According to the most recent statistics of CAPMAS* the unemployment rate of the age ranges from 18 to 29 is $26.7 \%$. Hence, it was essential to support such category in creating their own businesses, especially they have the interest and potential to become self-employed and more likely to believe that selfemployment is feasible.

7.4.3. Distribution of the sample members according to number of employees

Table(5) Descriptive Statistics For The Number of Employees

\begin{tabular}{|l|l|l|l|}
\hline \multirow{3}{*}{ Valid } & Frequency & Percent \\
\cline { 2 - 4 } & $1-10$ & 142 & 76.8 \\
\hline \multirow{3}{*}{ From the above table it is clear that $76.8 \%$ of the } \\
\cline { 2 - 4 } & Total & 38 & 20.5 \\
\hline \multirow{2}{*}{ Ther above } & 5 & 2.7 \\
\hline
\end{tabular}

entrepreneurships have number of employees from 1-10, where $20.5 \%$ of the entrepreneurships have number of employees from 11-19. Most of the entrepreneurships are in early stage as startups supported financially and technically by TIEC, Therefore, the no. of employees is still so limited ( up to 10 employees). Entrepreneurships with 20 employees and more didn't exceed $3 \%$ of the sample.

* http://www.capmas.gov.eg 
7.4.4. Distribution of the sample members according to the nature of the business

Table (6) Descriptive Statistics For The Nature of The Business

\begin{tabular}{|l|l|l|l|}
\hline \multirow{3}{*}{ Valid } & Frequency & Percent \\
\cline { 2 - 4 } & ICT & 93 & 50.2 \\
\cline { 2 - 4 } & ICT enabler & 92 & 49.8 \\
\cline { 2 - 4 } & Total & 185 & 100.0 \\
\hline
\end{tabular}

The table shows that $50.2 \%$ of the entrepreneurships in the sample are startups in ICT field, whereas $49.8 \%$ are ICT enablers who are incorporating ICTs in their core systems to contribute to developing different businesses aspects. These are the two categories that TIEC seeks out to finance and support technically.

7.4.5. Distribution of the sample members according to startup age

Table (7) Descriptive Statistics For The Startup age

\begin{tabular}{|l|l|l|l|}
\hline \multicolumn{2}{|l|}{} & Frequency & Percent \\
\hline \multirow{3}{*}{ Valid } & Less than 1 year & 121 & 65.4 \\
\cline { 2 - 4 } & 1 year - less than 5 years & 59 & 31.9 \\
\cline { 2 - 4 } & 5 years and above & 5 & 2.7 \\
\cline { 2 - 4 } & Total & 185 & 100.0 \\
\hline
\end{tabular}

The above table shows that $65 \%$ of the startups in the sample aged less than one year, whereas about $32 \%$ of the sample aged from one year to less than 5 years. This means that most of the sample startups still in the incubation period (i.e. within one year), while one third of it represents the recent graduated ones which are fully self-funded through its own operations. 
7.4.6. Summary of Descriptive Statistics for Independent, Moderator, and Dependent Variables

Table (8) Summary of descriptive statistics for independent, moderator, and dependent variables

\begin{tabular}{|l|l|l|l|}
\hline Variable & Mean & Std. Deviation & CV \\
\hline $\begin{array}{l}\text { Affective org. } \\
\text { commitment }\end{array}$ & 4.424 & .224 & $5.1 \%$ \\
\hline Innovativeness & 4.493 & .332 & $7.4 \%$ \\
\hline Risk-taking & 4.476 & .303 & $6.8 \%$ \\
\hline Proactiveness & 4.483 & .297 & $6.6 \%$ \\
\hline $\begin{array}{l}\text { Entrepreneurial } \\
\text { Orientation }\end{array}$ & 4.484 & .267 & $6.0 \%$ \\
\hline Business Incubator & 4.454 & .270 & $6.1 \%$ \\
\hline Org. Responsiveness & 4.505 & .273 & $6.1 \%$ \\
\hline
\end{tabular}

According to the previous descriptive statistics, it can be concluded that:-

- The two most homogeneous dimensions are: affective organization, and Entrepreneurial Orientation, with a coefficient of variation $(5.1 \%)$, and $(6 \%)$ respectively. The two most heterogeneous dimensions are: innovativeness, and risk-taking with a coefficient of variation (7.4\%), and (6.8\%) respectively. The mean for all dimensions are between 4 and 5 which indicate that most of the respondents agree and strongly agree to the questions that measured these dimensions. 
7.5. Correlation analysis

The following table represents the correlation between research variables:

Table (9) Correlation Analysis

\begin{tabular}{|c|c|c|c|c|c|c|c|}
\hline \multicolumn{8}{|c|}{ Correlations } \\
\hline & & 异 & & 象 & : & 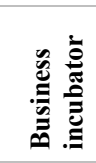 & 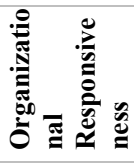 \\
\hline \multirow{3}{*}{$\begin{array}{l}\text { Affect } \\
\text { ive } \\
\text { org }\end{array}$} & $\begin{array}{l}\text { Pearson } \\
\text { Correlation }\end{array}$ & 1 & $.484^{* *}$ & $.642^{* * *}$ & $.469^{* * *}$ & $-.038-$ & .073 \\
\hline & Sig. (2-tailed) & & .000 & .000 & .000 & .505 & .203 \\
\hline & $\mathbf{N}$ & 185 & 185 & 185 & 185 & 185 & 185 \\
\hline \multirow{3}{*}{$\begin{array}{l}\text { Innov } \\
\text { ation }\end{array}$} & $\begin{array}{l}\text { Pearson } \\
\text { Correlation }\end{array}$ & $.484^{* * *}$ & 1 & $.827^{* k}$ & $.382^{k * k}$ & $-.072-$ & $.122^{*}$ \\
\hline & Sig. (2-tailed) & .000 & & .000 & .000 & .208 & .033 \\
\hline & $\mathbf{N}$ & 185 & 185 & 185 & 185 & 185 & 185 \\
\hline \multirow{3}{*}{$\begin{array}{l}\text { Risk- } \\
\text { taking }\end{array}$} & $\begin{array}{l}\text { Pearson } \\
\text { Correlation }\end{array}$ & $.642^{* k *}$ & $.827^{* *}$ & 1 & $.611^{\text {*** }}$ & .023 & .016 \\
\hline & Sig. (2-tailed) & .000 & .000 & & .000 & .681 & .777 \\
\hline & $\mathbf{N}$ & 185 & 185 & 185 & 185 & 185 & 185 \\
\hline \multirow{3}{*}{$\begin{array}{l}\text { Proact } \\
\text { ive }\end{array}$} & $\begin{array}{l}\text { Pearson } \\
\text { Correlation }\end{array}$ & $.469^{* * *}$ & $.382^{* *}$ & $.611^{\text {**k }}$ & 1 & .021 & $-.089-$ \\
\hline & Sig. (2-tailed) & .000 & .000 & .000 & & .718 & .117 \\
\hline & $\mathbf{N}$ & 185 & 185 & 185 & 185 & 185 & 185 \\
\hline \multirow{3}{*}{$\begin{array}{l}\text { Busin } \\
\text { ess } \\
\text { incub } \\
\text { ator }\end{array}$} & $\begin{array}{l}\text { Pearson } \\
\text { Correlation }\end{array}$ & $-.038-$ & $-.072-$ & .023 & .021 & 1 & $-.2211^{* * *}$ \\
\hline & Sig. (2-tailed) & .505 & .208 & .681 & .718 & & .000 \\
\hline & $\mathbf{N}$ & 185 & 185 & 185 & 185 & 185 & 185 \\
\hline \multirow{3}{*}{$\begin{array}{l}\text { Ent. } \\
\text { Respo } \\
\text { nsiven } \\
\text { ess }\end{array}$} & $\begin{array}{l}\text { Pearson } \\
\text { Correlation }\end{array}$ & .073 & $.122^{*}$ & .016 & -.089 & $-.221{ }^{* * *}$ & 1 \\
\hline & Sig. (2-tailed) & .203 & .033 & .777 & .117 & .000 & \\
\hline & $\mathbf{N}$ & 185 & 185 & 185 & 185 & 185 & 185 \\
\hline
\end{tabular}

From table (9), it is concluded that:

1- There is a significant, positive, moderate correlation between affective organizational commitment and each 
of innovativeness, risk taking and proactiveness with confident $95 \%$ as the p-value less than 0.05 .

2- There is a significant, positive, moderate correlation between innovativeness and each of affective organizational commitment, and proactiveness, whereas there is a significant, positive, strong correlation with risk- taking and a significant, positive, weak relation with organizational responsiveness with confident $95 \%$.

3- There is a significant, positive, moderate correlation between risk-taking and proactive this with confident $95 \%$ as the $p$-value less than 0.05 .

4- There is a significant, negative, weak correlation between business incubator and organizational responsiveness with confident $95 \%$ as the p-value less than 0.05 .

\subsection{Goodness of Fit}

The following table illustrates the goodness of fit Indices for the estimated SEM

Table (10) Goodness of Fit

\begin{tabular}{|l|l|}
\hline The goodness of fit Indices for the estimated SEM \\
\hline Chi-square & 558.72 \\
\hline Degree of freedom & 10 \\
\hline Level of significance & 0.000 \\
\hline Normed chi-square & 1.690 \\
\hline NFI & 0.79 \\
\hline RFI & 0.891 \\
\hline IFI & 0.789 \\
\hline TLI & 0.91 \\
\hline CFI & 0.786 \\
\hline
\end{tabular}

From the above table, it is concluded that all the goodness of fit measures of the model indicates that all indicators at 
acceptable limits, especially NFI (Normed Fit Index), RFI (Relative Fit Index), IFI (Incremental Fit Index), TLI (Tucker Lewis Index), and CFI (Comparative Fit Index) is close to one, and normed Chi-square with cut-off values is less than 5 . The fit measures indicate the goodness of fit of the proposed research framework and its ability to measure the relationship between the affective organizational commitment and the organizational responsiveness through the entrepreneurial orientation dimensions; innovativeness, risk-taking and proactiveness.

\section{Testing the Research Hypotheses}

To test hypotheses 1 and 2, regression analysis is used whereas to answer hypothesis 3 structural equations model is used by applying AMOS.

H1: Affective organizational commitment has a significant influence on Entrepreneurial orientation

Hla: Affective organizational commitment has a significant influence on innovativeness

H1b: Affective organizational commitment has a significant influence on risk-taking.

Hlc: Affective organizational commitment has a significant influence on proactiveness.

In order to answer these hypotheses, we need to estimate the following model:

Innovativeness

$=\beta_{0}+\beta_{1}$

* affective org.commitment

Risk taking

$=\beta_{0}+\beta_{1}$

* affective org.commitment 


$$
\begin{aligned}
& \text { Proactivness } \\
& \qquad \begin{aligned}
& \\
& * \beta_{0} \\
& * \text { affective org.commitment }
\end{aligned}
\end{aligned}
$$

\begin{tabular}{|c|c|c|c|c|c|c|c|c|}
\hline \multirow{2}{*}{$\begin{array}{l}\text { Dependent } \\
\text { variable }\end{array}$} & \multirow{2}{*}{$\begin{array}{l}\text { Independent } \\
\text { variable }\end{array}$} & \multicolumn{2}{|c|}{ Coefficient } & \multicolumn{2}{|c|}{$\begin{array}{l}\text { Constant } \\
\text { term }\end{array}$} & \multirow{2}{*}{$\begin{array}{l}\text { Adjuste } \\
\text { r R- } \\
\text { Square } \\
\text { d } \\
\end{array}$} & \multirow[b]{2}{*}{ F-test } & \multirow[b]{2}{*}{ Sig. } \\
\hline & & $\begin{array}{l}\text { Valu } \\
\mathrm{e}\end{array}$ & sig. & $\begin{array}{l}\text { valu } \\
\mathrm{e}\end{array}$ & Sig. & & & \\
\hline $\begin{array}{l}\text { innovativenes } \\
\text { s }\end{array}$ & $\begin{array}{l}\text { Affective } \\
\text { organization } \\
\text { al } \\
\text { commitment }\end{array}$ & 0.716 & $\begin{array}{l}0.00 \\
0\end{array}$ & $\begin{array}{l}1.32 \\
3\end{array}$ & $\begin{array}{l}0.00 \\
0\end{array}$ & 0.232 & 93.788 & $\begin{array}{l}0.00 \\
0\end{array}$ \\
\hline Risk- taking & $\begin{array}{l}\text { Affective } \\
\text { organization } \\
\text { al } \\
\text { commitment }\end{array}$ & 0.869 & $\begin{array}{l}0.00 \\
0\end{array}$ & $\begin{array}{l}0.63 \\
3\end{array}$ & $\begin{array}{l}0.01 \\
6\end{array}$ & 0.41 & $\begin{array}{l}215.00 \\
8\end{array}$ & 0.00 \\
\hline Proactiveness & $\begin{array}{l}\text { Affective } \\
\text { organization } \\
\text { al } \\
\text { commitment }\end{array}$ & 0.621 & $\begin{array}{l}0.00 \\
0\end{array}$ & $\begin{array}{l}1.73 \\
6\end{array}$ & $\begin{array}{l}0.00 \\
0\end{array}$ & 0.217 & 86.579 & $\begin{array}{l}0.00 \\
0\end{array}$ \\
\hline
\end{tabular}

Table (11) Regression Analysis between Affective organizational commitment and Entrepreneurial orientation

From the above the table we can conclude that:

1- All items of Entrepreneurial orientation; innovativeness, risktaking and proactiveness are affected by affective organizational and this effect is positive. This with confident $95 \%$ as there $\mathrm{p}$-value is less 0.05 , and this appear from sig. column.

2- From adjusted R-square column, it is clear that the affective organizational commitment describes around $23.2 \%$ of the variation of innovativeness, while it describes $41 \%$ of the variation of risk taking, and describes $21.7 \%$ of the variation of pro-activeness. Effective organizational commitment has the highest influence on the risk-taking. Then the estimated models are as follows: 


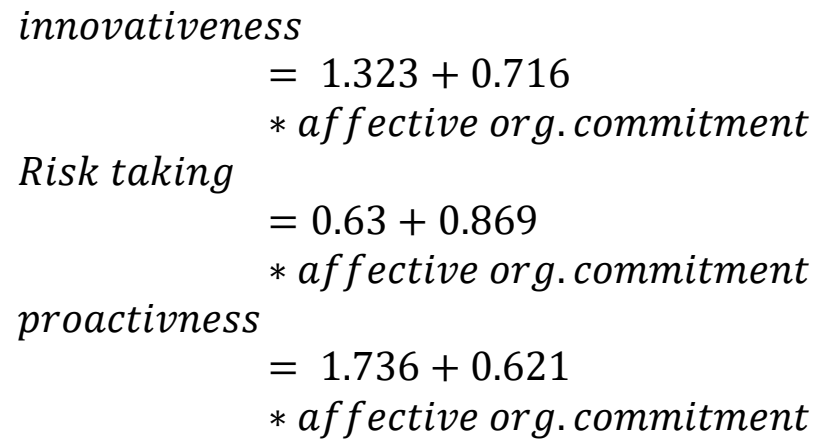

It can be concluded that an increase in the affective organizational commitment can cause an increase in the entrepreneurial orientation, especially in risk taking. This means that affective organizational commitment can support one of the most important characteristics of the entrepreneurships; risk taking as such commitment helps in teaching the employees properly how to act under pressure, and when it is suitable to take a risk and when it is not. Organizational commitment can provide a supportive environment to encourage risk taking, hence, the entrepreneurship members become more passionate regarding their tasks in a coordinated manner and more able to handle the risk taking processes; not only in allocating adequate budget and resources, but also accountability for consequences that may arise from risk taking.

Depend on the above we will accept that

H1: Affective organizational commitment has a significant influence on Entrepreneurial orientation

Hla: Affective organizational commitment has a significant influence on innovativeness

$H 2 b$ : Affective organizational commitment has a significant influence on risk-taking.

H2c: Affective organizational commitment has a significant influence on proactiveness. 
H2: Entrepreneurial orientation in startups has a significant influence on organizational responsiveness

H2a: Innovativeness in startups has a significant influence on organizational responsiveness.

H2b: Risk- taking in startups has a significant influence on organizational responsiveness.

H2c: Proactiveness in startups has a significant influence on organizational responsiveness.

To test these hypotheses the following model is estimated; organizational responsiveness

$$
\begin{aligned}
& =\beta_{0}+\beta_{1} * \text { innovativeness }+\beta_{2} \\
& * \text { risk taking }+\beta_{3} * \text { proactiveness }
\end{aligned}
$$

The results are presented in the following table:

Table (12) Regression Analysis between Entrepreneurial

\begin{tabular}{|c|c|c|c|c|c|c|c|c|}
\hline \multirow{2}{*}{ 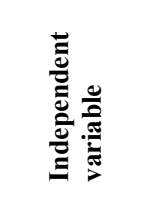 } & \multirow{2}{*}{ 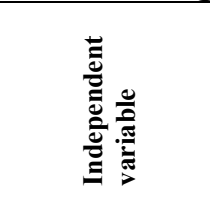 } & \multicolumn{2}{|c|}{ Coefficient } & \multicolumn{2}{|c|}{ Constant term } & \multirow{2}{*}{ 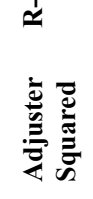 } & \multirow[b]{2}{*}{$\begin{array}{l}\text { F- } \\
\text { test }\end{array}$} & \multirow[b]{2}{*}{ Sig. } \\
\hline & & Value & sig. & value & Sig. & & & \\
\hline $\begin{array}{l}\text { innovative } \\
\text { ness }\end{array}$ & \multirow{3}{*}{$\begin{array}{l}\text { organizational } \\
\text { responsiveness }\end{array}$} & 0.250 & 0.004 & 4.493 & 0.000 & \multirow{3}{*}{0.034} & \multirow{3}{*}{$\begin{array}{l}4.5 \\
60\end{array}$} & \multirow{3}{*}{$\begin{array}{l}0.0 \\
04\end{array}$} \\
\hline $\begin{array}{l}\text { Risk- } \\
\text { taking }\end{array}$ & & -0.15 & 0.15 & & & & & \\
\hline $\begin{array}{l}\text { Proactiven } \\
\text { ess }\end{array}$ & & -0.09 & 0.18 & & & & & \\
\hline
\end{tabular}
Orientation and Organizational Responsiveness

From the above the table we can conclude that:

1- The overall model is significant with confident $95 \%$, as the $\mathrm{p}$-value of F-test less than 0.05

2- Organizational responsiveness is affected positively by innovation only with confident $95 \%$, while there is no effect of risk-taking, and proactiveness on organizational responsiveness. 
3- From adjusted R-square column, it is clear that the estimated model describes around $3.4 \%$ of the variation of organizational responsiveness

4- Then the estimated model is as follows:

organizational responsiveness

$$
=4.493+0.25 * \text { innovativeness }
$$

Depend on the above model we can accept that

H2a: Innovativeness in startups has a significant influence on organizational responsiveness.

\section{While reject that:}

$H 2 b$ : Risk-taking in startups has a significant influence on organizational responsiveness.

H2c: Proactiveness in startups has a significant influence on organizational responsiveness.

It can be concluded that innovativeness is an important driver of organizational responsiveness as it improves the firm's ability to react quickly to changing market demands. Innovativeness allows entrepreneurships to promptly act on market opportunities which helps in developing new ideas tailored to customer preferences more effectively than their competitors and well received by their customers (Liao et al., 2003). On the other hand both of risk taking and proactiveness have no significant impact on organizational responsiveness, as the entrepreneurs have to expect day-to-day challenges should be faced and decisions must be made to keep up with the needs of the target market proactively. Such practices may conflict the core concept of organizational responsiveness as the latter is obsessed with beating the competition within the current market conditions which may differ from discovering, understanding and satisfying latent and prospective customer needs. 
H3: Business incubator moderates the relationship between entrepreneurial orientation and organizational responsiveness.

To test this hypothesis, structural equations model is done by using AMOS. However, to say that business incubator has a significant effect on the relation between entrepreneurial orientation items and organizational responsiveness, significant relation between both; entrepreneurial orientation items and business incubator and business incubator and organizational responsiveness. Hence, the following figure represents path analysis diagram and the table represents the cstimatcs:

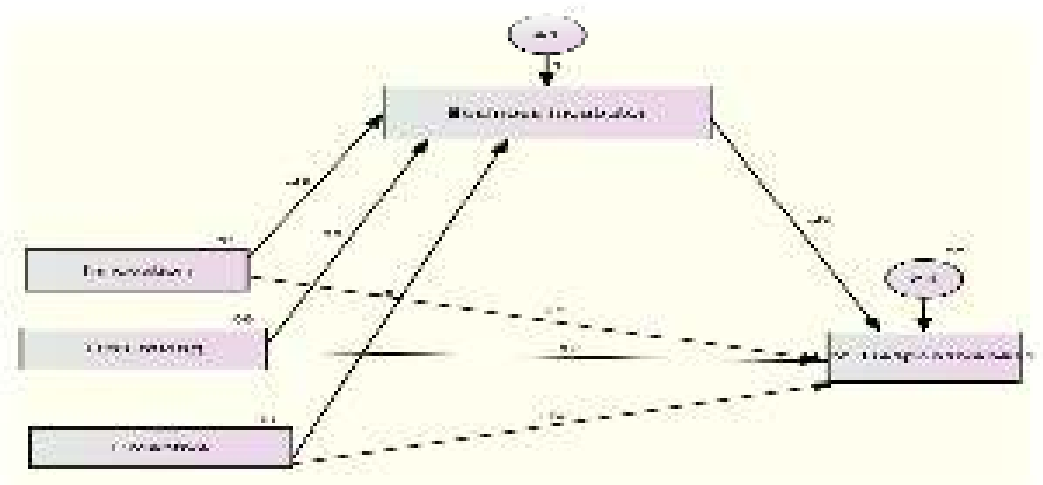

Jiģure (2) racb Analysia Diag̣'ara 
Table (13) Regression Weights: (Group no. 1- Default model)

\begin{tabular}{|c|c|c|c|c|c|c|c|}
\hline & & & Estimate & S.E. & C.R. & $\mathrm{P}$ & Label \\
\hline Business incubator & $<--$ & Innovation & -.251 & .046 & -5.492 & **** & \\
\hline Business incubator & $<-$ & Risk taking & .275 & .050 & 5.514 & *** & \\
\hline Business incubator & $<--$ & Proactiveness & -.046 & .051 & -.905 & .366 & \\
\hline $\begin{array}{l}\text { Org. } \\
\text { Responsiveness }\end{array}$ & $<--$ & Innovativeness & 199 & .047 & 4.241 & **** & \\
\hline $\begin{array}{l}\text { Org. } \\
\text { Responsiveness }\end{array}$ & $<-$ & Risk taking & -.102 & .051 & -1.983 & .047 & \\
\hline $\begin{array}{l}\text { Org. } \\
\text { Responsiveness }\end{array}$ & $<--$ & Proactiveness & -.100 & .050 & -1.986 & .047 & \\
\hline $\begin{array}{l}\text { Org. } \\
\text { Responsiveness }\end{array}$ & $<-$ & $\begin{array}{l}\text { Business } \\
\text { incubator }\end{array}$ & -.200 & .056 & -3.578 & $* * *$ & \\
\hline
\end{tabular}

From the above table we can conclude that:

- There is a significant relation between innovativeness and business incubator; as well there is a significant relation between business incubator and organizational responsiveness. The direct effect of innovation on organizational responsiveness is 0.2 while the indirect effect is $0.2 *-0.2=-0.04$. This means that business incubator has significant effect on the relation between innovativeness and organizational responsiveness. However, the business incubator weakens such relation and converts it into a negative one. This means that the role of business incubator affects negatively on the relation between innovativeness and organizational responsiveness.

- There is significant relation between risk-taking and business incubator, as well there is significant relation between business incubator and organizational responsiveness. The direct effect of innovation on organizational responsiveness is -0.12 while the indirect effect is $-0.12 *-0.2=0.024$. This means that business incubator has significant effect on the relation between risk-taking and organizational responsiveness the business incubator lead this relation to be less and positive. This mean that increasing business 
incubator make the relation between risk-taking and organizational resp. is positive

- Business incubator has no significant effect on the relation between proactiveness and organizational responsiveness, as there is no significant relation between proactiveness and business incubator. However the direct effect of proactiveness on organizational responsiveness is -0.1 .

Depending on the above, we accept that: business incubator moderates the relationship between entrepreneurial orientation (i.e. innovation, and risk-taking) and organizational responsiveness. We can summarize the direct and indirect effects in the following table:

Table (14) Direct and Indirect Effect of EO Dimensions on Organizational Responsiveness

\begin{tabular}{|l|l|l|l|}
\hline \multicolumn{4}{|c|}{ The direct and indirect effect of innovation, risk-taking, pro-activeness on } \\
organizational responsiveness through business incubator: \\
\hline & Innovativeness & Risk-taking & Proactiveness \\
\hline Direct & 0.2 & -0.12 & -0.1 \\
\hline Indirect & -0.04 & 0.024 & - \\
\hline
\end{tabular}

From table (14), it can be concluded that business incubator practices improve the risk-taking impact on the organizational responsiveness as the direct effect was negative, while in the presence of the business incubator the relationship is converted into a positive one. In contrast, the direct positive relationship between the innovativeness and the organizational responsiveness is converted into a negative one in the existence of the business incubator. However, it has no effect on the relationship between proactiveness and the organizational responsiveness. 
ble (15) Moderator Test result for business incubator as a moderator variable

\begin{tabular}{|l|l|l|l|}
\hline & Chi-square & DF & Sig. \\
\hline Overall model & \multicolumn{3}{|l|}{} \\
\hline Unconstrained & 243.021 & 15 & \\
\hline Fully constrained & 280.63 & 12 & \\
\hline Number of groups & & 2 & \\
\hline Difference & 523.651 & 3 & 0.000 \\
\hline
\end{tabular}

Based on the moderator's test results, business incubator has a significant positive effect on the relation between risk taking and organizational responsiveness as it aids the startups to overcome the obstacles they face through providing them with various services such as, access infrastructure, marketing and financial aid and technical support. However, the business incubator has a significant but a negative impact on the relation between innovativeness and organizational responsiveness since its role is to assist them financially and technically which requires a time commitment of the first business year, plus adherence to certain regulations set by the incubator, which includes many constraints consume a fair amount of time doing it. Such practices may constraint its abilities of innovativeness and consequently deteriorate its impact on the organizational responsiveness.

However, it has no effect on the relation between proactiveness and organizational responsiveness as concluded that there is no significant impact of the proactiveness on the organizational responsiveness even in the presence of the business incubator. The difference between these two approaches proactiveness and organizational responsiveness is the perspective each one provides in assessing actions and events; the first focuses on eliminating problems before occurrence, whereas the latter is based on responding to events and problems after they have happened. 


\section{Discussion and Conclusion}

Concurrent with businesses' increasing desire to be more entrepreneurial, the body of research on EO has been growing at a rapid rate (Simon et al., 2011). Hence, the purpose of this research is to measure the mediating role of EO on the relationship between affective organizational commitment and organizational responsiveness in the presence of business incubator. The key determinants of EO are; innovativeness, risk taking and proactiveness. It also studies the moderating effect of business incubator on the relationship between entrepreneurial orientation and organizational responsiveness. $H 1$ is hypothesized as "Affective organizational commitment has a significant influence on Entrepreneurial orientation". As the results suggest, employees expected to identify themselves as part of a social category as influenced by their self-concept and membership in a social body for which they belong (Dutton et al.,1994). Hence, this research agreed with (Ugaddan et al., 2016) about the positive relationship between affective organizational commitment and entrepreneurial orientation with respect to all of its dimensions; innovativeness, risk taking and proactiveness. $\mathrm{H} 2$ is hypothesized as "Entrepreneurial orientation has a significant influence on organizational responsiveness" as a direct relationship without any moderators. However, it is proved partially through one component only of EO; the innovativeness. As agreed upon by Morgan, (2012), Morgan et al., (2009) and Liao et al., (2003), innovativeness is considered as a key player in responding to changes in market demands and improving the entrepreneurship's ability to react quickly to market opportunities which helps in developing new ideas tailored to customer preferences more effectively than their competitors. $H^{\mu}$ is hypothesized as "business incubator moderates the relationship between entrepreneurial 
orientation and organizational responsiveness". Again, it is proved partially through the moderating role of business incubator between only two components of entrepreneurial orientation (i.e. innovativeness and risk taking). However, it has a negative impact on the relationship between innovativeness and organizational responsiveness. This result is consistent with Bruneel et al., (2012) as the business incubator imposes its rules, regulations and controls on the entrepreneurships which should be applied strictly during the incubation year to get the financial and the technical aids. Also, offering similar support services for all of the entrepreneurships' generations make less utilization of the incubator's service portfolio in addition to the absence of clearly defined exit policies.

Nevertheless, this result is inconsistent with Hackett and Dilts, (2004b) and Ndubisi, (2014) who argued that policymakers highly support business incubators because they can generate innovation and growth by helping new businesses avoid failure through affecting positively on their organizational responsiveness. Moreover, they consider such reason is the answer of a question; why the number of business incubators has been rising rapidly around the world? (Ratinho, 2011, Ratinho and Henriques 2010, Schwartz and Gothner 2009, Phan et al. 2005). Also, business incubator has a positive impact on the relationship between risk taking and organizational responsiveness. This result is consistent with Şehitoğlu and Özdemir (2013) and Amezcua (2010) findings as they argued that the incubation helps new ventures grow faster than nonincubated ones and enables them to develop stronger capacities to compete and grow. Also, it can help in protecting businesses from competitive forces of the external environment and increase the likelihood of survival as it is considered as a supporter of any risk-taking during the whole incubation period, 
- especially financial and technology associated risks- which make them more responsive to the customers and the markets.

In conclusion, the results of this research reveal that the affective organizational commitment has strong ties with entrepreneurial orientation. From a practical perspective, In addition to being less likely to leave their startups, individuals with higher levels of affective commitment are more likely to have better interest in innovativeness, risk-taking and proactiveness. Also, entrepreneurship orientation has a positive impact on the organizational responsiveness, whereas there has been a common assumption that business incubation positively affects the relationship between entrepreneurship orientation and organizational responsiveness not only during incubation period but also after graduation. However, the study focused on the need to develop the role of the business incubator as its role has to go beyond just offering a space and source of funding. It has to support the innovation process, shared learning, mentorship, faster access to various funding grants that are all vital for any new start-up to kick-starting a new business and put it ahead of the competition to enjoy accelerated growth in the future. 


\section{Implications}

\subsection{Implications for Theory}

This study contributes to the literature in two ways. First of all it adds some knowledge to the literature on the affective organizational commitment and its impact on the entrepreneurial orientation in terms of innovativeness, risk-taking and proactiveness. Second, it emphasizes on the importance of entrepreneurial orientation's impact with all of its dimensions on the organizational responsiveness. Moreover it helps to shed light on how can business incubators be successful in supporting startups as it focuses on its role to accelerate the successful development of them through an array of business support resources and services.

\subsection{Implications for Policy}

Although there are some problems about the role of the business incubator as a moderator between innovativeness and proactiveness from one side and the organizational responsiveness from the other side, still business incubator has a significant impact on the relationship between overall entrepreneurial orientation and organizational responsiveness. Therefore, business incubator's policy should be developed and improved, especially the exit policy, in order to maximize the benefits of on-incubators startups.

\subsection{Limitations and Future Research}

This research has some limitations. Firstly, the research is basically limited to data from incubated startups by TIEC which is one of the affiliate organizations of Ministry of Communications and Information Technology (MCIT). Such issue may impose some limitations to the data used in this study. In other words, in order to make some generalizations it will be beneficial to conduct similar researches in other sectors in Egypt. Also, comparative study between incubated and non-incubated startups may be conducted and concludes different findings. Additionally, further researches may 
broaden the study to other developing countries and may shed light on the dynamics of business incubation and gives a clear comparison between different societies and cultures. Moreover, future researches may use different statistical techniques which may end with different results.

\section{References}

Abduh, M., D’Souza, C., Quazi, A., Burley, H. T. (2007). " Investigating and Classifying Clients' Satisfaction with Business Incubator Services". Managing Service Quality, 17(1), 74-91.

Ackah, A.J. (2011). "The Challenges Faced by Small \& Medium Enterprises (SMEs) in Obtaining Credit in Ghana". Blekinge Tekniska Hogskola.

Aernoudt, R. (2004). "Incubators: Tool for Entrepreneurship?" Small Business Economics, 23(2), 127-135.

Allen, N. J., \& Meyer, J. P. (1990). "The measurement and antecedents of affective, continuance and normative commitment to the organization". Journal of occupational psychology, 63(1), 1-18.

Ames, M. and Runco, M. (2005). "Predicting entrepreneurship from ideation and divergent thinking". Creativity and Innovation Management 14(3), 311-315.

Amezcua, A. S. (2010). "Performance analysis of entrepreneurship policy: which business incubators generate the highest levels of economic performance?". Frontiers of Entrepreneurship Research 30 (18), article (1).

Anlesinya, Alex; Eshun, Patrick; Bonuedi, Amy Afi, (2015) "Entrepreneurial Orientation dimensions and Profitability Nexus: Evidence from Enterprises in The Retail Sector in a Developing Country", International Journal of Small Business and Entrepreneurship Research, 3(7),79-87.

Baron, R.A., (2007). Behavioural and cognitive factors in entrepreneurship: Entrepreneurs as the active element in new 
venture creation. Strategic Entrepreneurship Journal, 1,167182.

Bayhan, A. (2006), "Business incubator process: A policy tool for entrepreneurship and enterprise development in a knowledge- based economy". Retrieved from: http://pdf.usaid.gov/pdf_docs/Pnadt103.pdf

Berenson, M. L.; Levine, D. M. and Szabat, K. (2013), "Estimation and Sample Size Determination for Finite Populations", Basic Business Statistics: Global Edition.

Bergek , A. and Norrman , C. (2008). "Incubator best practice: A framework", Technovation, (28), 1-2, 20-28.

Bollingtoft, A. and Ulhoi, J. P. (2005). "The networked business incubator--leveraging entrepreneurial agency?" Journal of Business Venturing, 20(2), 265-290.

Bruneel, J., Ratinho, T., Clarysse, B. and Groen, A. (2012) "the evolution of business incubators: comparing demand and supply of business incubation services across different incubator generations." Technovation, 32 (2), 110-121.

Casillas, J. C., Moreno, A. M., \& Barbero, J. L. (2009). "A configurational approach of the relationship between entrepreneurial orientation and growth of family firms". Family Business Review, 23(1), 27-44.

Cegarra-Navarro, J.G. and Martinez-Conesa, E.A. (2007). "Ebusiness through knowledge management in Spanish telecommunications companies". International Journal of Manpower, 28(3/4), 298-314.

Chan, K. F. and Lau, T. (2005). "Assessing technology incubator programs in the science park: the good, the bad and the ugly". Technovation, 25(10), 1215-1228. 
Chen, M. H., (2007). "Entrepreneurial leadership and new ventures: creativity on entrepreneurial teams". Creativity and Innovation Management, 16(3), 239-249.

Chess , Caron. (1999). "A Model of Organizational Responsiveness to Stakeholders, RISK: Health, Safety \& Environment". Risk Communication in a Democratic Society, 10(3), 257-267.

Chughtai, A.A. (2013), "Linking affective commitment to supervisor to work outcomes", Journal of Managerial Psychology, 28 (6), 606-627.

Collinson, S. and Gregson, G. (2003). "Knowledge networks for new technology-based firms: an international comparison of local entrepreneurship promotion". $R \& D$ Management, 33(2), 189-208.

Covin, J. G. and Wales, W. J., (2012), "The Measurement of Entrepreneurial Orientation", Entrepreneurship Theory and Practice, 36(4), 677-702.

Covin, J.G., Green, K.M., \& Slevin, D.P. (2006). "Strategic Process Effects on the Entrepreneurial Orientation-Sales Growth Rate Relationship". Entrepreneurship Theory and Practice, 30(1), 57-81.

Crant, J. (1996). "The proactive personality scale as a predictor of entrepreneurial intentions". Journal of Small Business Management, 34(3), 42-49.

Cromie, S. (2000). Assessing entrepreneurial inclinations: Some approaches and empirical evidence. European Journal of Work and Organizational Psychology 9(1): 7-30.

De Clercq, D., Dimov, D., \& Thongpapanl, N. T. (2009). "The moderating impact of internal social exchange processes on the entrepreneurial orientation-performance relationship", Journal of Business Venturing, 25(1), 87-103. 
Delle, E. and Amadu, I. M. (2015), "Proactive personality and entrepreneurial intention: employment status and student level as moderators", International Journal of Small Business and Entrepreneurship Research, 3(4), 1-13.

Den Hartog, D. N.; and Belschak, F. D. (2007). "Commitment, affect and initiative at work". Journal of Occupational and Organizational Psychology, 80, 601-622.

Dutton, J. E., Dukerich, J. M., and Harquail, C. V. (1994). "Organizational images and member identification", Administrative science quarterly, 239-263.

Ekstein, Karen L., (2007). "Organizational responsiveness as a strategic core competence in dynamic and complex environments: an exploratory developmental framework". Published Ph.D. dissertation, York University (Canada).

Felício, J. A., Rodrigues, R., \& Caldeirinha, V. R. (2012). "The effect of entrepreneurship on corporate performance". Management Decision, 50(10), 1717-1738.

Garrett, R.P.; Covin, J.G. and Slevin, D.P. (2009), "Market responsiveness, top management risk taking, and the role of strategic learning as determinants of market pioneering", Journal of Business Research, 62(8), 782-788.

Gebert, H., Geib, M., Kolbe, L. \& Riempp, G. (2002). "Towards customer knowledge management: Integrating customer relationship management and knowledge management concepts". Paper presented at the $2^{\text {nd }}$ International Conference on Electronic Business, Taipei, Taiwan.

Gellatly, I.R., Meyer, J.P. and Luchak, A.A. (2006), “Combined effects of the three commitment components on focal and discretionary behaviours: a test of Meyer and Herscovitch's propositions", Journal of Vocational Behaviour, 69 (2), 331345. 
Green, K.M.; Covin, J.G.; and Slevin, D.P. (2008). "Exploring the relationship between strategic reactiveness and entrepreneurial orientation: The role of structure-style fit". Journal of Business Venturing, 23(3), 356-383.

Gudermann, M. (2010). "The relationship between proactive personality, affective commitment and the role of job stressors". Retrieved from http://essay.utwente.n1/59941/1/BSc_M_Gudermann.pdf Gupta, V.; MacMillan, I. C.; and Surie, G. (2004). "Entrepreneurial leadership: developing and measuring a crosscultural construct". Journal of Business Venturing, 19(2), 241260.

Gürol, Y., and Atsan, N. (2006). "Entrepreneurial characteristics amongst university students: Some insights for entrepreneurship education and training in Turkey". Education + Training, 48(1), $25-38$.

Hackett, S. M. and Dilts, D. M. (2004b). "A Real OptionsDriven Theory of Business Incubation". The Journal of Technology Transfer, 29(1), 41-54.

Hackett, S.M. and Dilts, D.M. (2004a) "A systematic review of business incubation Research", The Journal of Technology Transfer, 29(1), 55-82.

Hakimian, F., Farid, H., Ismail, M.N. and Nair, P.K. (2016), "Importance of commitment in encouraging employees' innovative behaviour", Asia-Pacific Journal of Business Administration, 8 (1), 70-83.

Hansen, J. D., Deitz, G. D., Tokman, M., Marino, L. D., \& Weaver, K. M. (2011). "Cross-national invariance of the entrepreneurial orientation scale". Journal of Business Venturing, 26(1), 61-78. 
Helo, P. (2004), "Managing agility and productivity in the electronics industry", Industrial Management \& Data Systems, 104 (7), 567-577.

Hisrich, R. D., Peters, P. M., and Shepard, D. A. (2008)." Entrepreneurship". Singapore: Mc Graw Hill International Edition.

Homburg, C., Grozdanovic, M., and Klarmann, M. (2007). "Responsiveness to customers and competitors: the role of affective and cognitive organizational systems". Journal of Marketing, 71, 18-38.

Hsu, P., Shyu, J. Z., Yu, H., Yuo, C. and Lo, T. (2003). "Exploring the interaction between incubators and industrial clusters: the case of the itri incubator in Taiwan. $R \& D$ Management, 33(1), 79-90.

Hughes, M. and Morgan, R.E.(2007)."Deconstructing the relationship between entrepreneurial orientation and business performance at the embryonic stage of firm growth". Industrial Marketing Management, 36, 651-661.

Hughes, M., Hughes, P. and Morgan, R. E. (2007). "Exploitative Learning and Entrepreneurial Orientation Alignment in Emerging Young Firms: Implications for Market and Response Performance". British Journal of Management, 18(4), 359-375.

Hult, G. T., Ketchen, D. J., and Slater, S. F. (2005). "Marketing orientation and performance: an integration of disparate approaches". Strategic Management Journal, 26, 1173-1181.

Karam, A. (2017). "CEO Entrepreneurial Characteristics and the Entrepreneurial Orientation of the Firm", Master's thesis, Concordia University, Montreal, Quebec, Canada

Kickul, J., \& Gundry, L. (2002). "Prospecting for strategic advantage: The proactive entrepreneurial personality and small firm innovation". Journal of Small Business Management, 40(2), 85-97. 
Koh, H. (1996). "Testing hypotheses of entrepreneurial characteristics". Journal of Managerial Psychology 11(3), 1225.

Kohli, , A. K., and Jaworski, B. J, (1990) "Market orientation: the construct, research propositions and managerial implications", Journal of Marketing, 54, 1-18.

Lamore, P. R.; Berkowitz, D. and Farrington, P. A. (2013). "Proactive/Responsive market orientation and marketingresearch and development integration". Journal of product innovation management, 30(4), 695-711.

Landy, F.J., and Conte. J.M., (2006). "Work in the 21st Century". New York: Blackwell Publishing.

Lechner, C. and Gudmundsson, S.V. (2014), "Entrepreneurial orientation, firm strategy and small firm performance", International Small Business Journal, 32 (1), 36-60.

Lechner, C., Gudmundsson, S.V. (2014), "Entrepreneurial orientation, firm strategy and small firm performance". International Small Business Journal, 32(1), 36-60.

Leiponen, A. and Helfat, C.E. (2003). "Innovation Objectives, Knowledge Sources, and the Benefits of Breadth". Unpublished manuscript, Cornell University, Ithaca, NY.

Lesákova, L. (2012). "The Role of Business Incubators in Supporting the SME Start-up", Acta Polytechnica , Hungarica, 9(3), 85-95. 
Liao, J.; Welsch, H. and Stoica, M. (2003). "Organizational Absorptive Capacity and Responsiveness: An Empirical Investigation of Growth-Oriented SMEs", 28(1), 63-85.

Liu, X.-P. and Wang, Z.-M. (2013). "Perceived risk and organizational commitment: the moderating role of organizational trust". Social Behavior and Personality, 41(2), 229-240.

Liu, Y., Keller, R.T. and Shih, H.A. (2011), "The impact of team-member exchange, differentiation, team commitment, and knowledge sharing on R\&D project team performance.", $R$ and D Management, 41 (3), 274-287.

Lose, T. and Tengeh , R. K.(2015). "The Sustainability and Challenges of Business Incubators in the Western Cape Province, South Africa", Sustainability, 7, 14344-14357.

Lumpkin, G. T. and Dess, G.G. (1996), "Clarifying the Entrepreneurial Orientation Construct and Linking It to Performance", the Academy of Management Review, 21(1), 135172.

Lumpkin, G.T. and Dess, G. G., (2001), "Linking Two Dimensions of Entrepreneurial Orientation to Firm Performance: The Moderating Role of Environment and Industry Life Cycle", Journal of Business Venturing, 16, 429451.

Luu, T., (2017) "Market responsiveness: antecedents and the moderating role of external supply chain integration", Journal of Business \& Industrial Marketing, 32 (1), 30-45.

Lyons, T. S., Li, S. (2003). "The State of the Wisconsin Incubation Industry in 2002: An Analysis of the Results of the Survey of Membership". Report prepared for The Wisconsin Business Incubation Association.

Marshall, C., and Rossman, G. (1999). "Designing qualitative research". London: SAGE Publishing 
Meyer, J.P., Stanley, D.J., Herscovitch, L. \& Topolnytsky, L. (2002). "Affective, Continuance, and Normative Commitment to the Organization: A Meta-analysis of Antecedents, Correlates, and Consequences". Journal of Vocational Behavior, 61, 20-52. Miller, D. (1983). "The correlates of entrepreneurship in three types of firms". Management Science, 29(7), 770-791.

Möller, K., Pels, J. and Saren, M. (2009). "The marketing theory or theories into marketing? Plurality of research traditions and paradegms". In MacIaran, P; Saren, M., Stern, B.; Tadajewski. The Sage handbook of Marketing Theory. Los Angeles: Sage.

Morgan, N. A. (2012). "Marketing and business performance". Journal of the Academy of Marketing Science, 40, 102-119.

Morgan, N. A.; Vorhies, D. W. and Mason, C. H. (2009). "Market orientation, marketing. capabilities and firm performance", Strategic management Journal, 30 , 909-920.

Naldi, L.; Nordqvist, M.; Sjöberg, K. and Wiklund, J., (2007), "Entrepreneurial Orientation, Risk Taking, and Performance in Family Firms", Family Business Review, XX (1), Family Firm Institute, Inc.

Narver, J. C., and Slater, S. F. (1990). "The effect of a market orientation on business profilability". Journal of Marketing, 54, 20-35.

Ndubisi, N. O. (2014). "Entrepreneurship and service innovation", Journal of Business \& Industrial Marketing, 29 (6), 449-453.

Ng, Y., Lee, V., Foo, A.T. and Gan, P. (2012). "The relationship between knowledge management practices and technological innovation: A conceptual framework". International Journal of Management, Knowledge and Learning, 1(1), 71-89.

Nolan, A. (2003). "Public policy on business incubators: an OECD perspective". Journal of Entrepreneurship and Innovation Management, 3(1/2), 22-30. 
Oni, E. O., (2012). "Relevance of entrepreneurial proactiveness on business performance: Nigerian companies experience". Arabian Journal of Business and Management Review, 1(6), 92108.

Pelham, A. (2000). "Market orientation and other potential influences on performance in small and medium-sized manufacturing firms". Journal of Small Business Management , 38 (1), 48- 67.

Peters, L., Rice, M. and Sundararajan, M. (2004). "The Role of Incubators in the Entrepreneurial Process". Journal of Technology Transfer, 29(1), 83-91.

Phan, P., Siegel, D. and Wright, M. (2005). "Science parks and incubators: observations, synthesis and future research", Journal of Business Venturing, 20, 165-182.

Pishdad, A. and Haider, A., (2013). "Responding to external and internal changes: Organizational responsiveness pressures in institutionalising ERP systems", Portland International Conference on Management of Engineering and Technology, PICMET 2013; San Jose, CA; United States. PMBOK Guide, (2008)."A Guide to the Project Management Body of Knowledge". Fourth Ed., Project Management Institute, Pennsylvania , USA.

Ratinho, T. (2011). "Are they helping? An examination of business incubators' impact on tenant firms", PhD thesis.

Ratinho, T. and Henriques, E. (2010) "the role of science parks and business incubators in converging countries: The Portuguese case", Technovation, 30 (4), 278-290.

Rauch, A., and Frese, M. (2007). "Let's put the person back into entrepreneurship research: A meta-analysis on the relationship between business owners' personality traits, business creation, and success". European Journal of Work and Organizational Psychology, 16(4), 353-385. 
Rauch, A., Wiklund, J., Lumpkin, G.T., Frese, M. (2009), "Entrepreneurial orientation and business performance: An assessment of past research and suggestions for the future". Entrepreneurship Theory and Practice, 33(3), 761-787.

Rhoades, L.;Eisenberger, R.; Armeli, S. (2001)." Affective Commitment to the Organization: The Contribution of Perceived Organizational Support", Journal of Applied Psychology, 86(5), 825-836.

Rubera, G and Kirca, A. H. (2012). "Firm innovativeness and its performance outcomes: A meta analytic review and theoretical integration". Journal of Marketing ,76, 130-147.

Runyan, R. C., Ge, B., Dong, B., and Swinney, J. L. (2012). "Entrepreneurial Orientation in Cross-Cultural Research: Assessing Measurement Invariance in the Construct". Entrepreneurship Theory and Practice, 36(4), 819-836.

Schwartz, M. and Gothner M. (2009) "A novel approach to incubator evaluations: the promethee outranking procedures", IWH Discussion Papers 1, Halle Institute for Economic Research.

Şehitoğlu, O. C. and Özdemir, Y.(2013). "Assessing the impacts of technology business incubators: A framework for technology development centers in Turkey", 2nd International conference on leadership, technology and innovation management. Procedia - Social and Behavioral Sciences, 75, 282 - 291.

Shane, S.; Kolvereid, L.; Westhead, P. (1991). "An exploratory examination of the reasons leading to new firm formation across country and gender. Journal of Business Venturing 6(6): 431-446.

Shane, S.; Locke, E.; and Collins, C., (2003) . "Entrepreneurial motivation". Human Resource Management Review, 13, 257279.

Simon, M.; Stachel, C.; and Covin, J. G. (2011). "The Effects of Entrepreneurial Orientation and Commitment to Objectives on 
Performance", New England Journal of Entrepreneurship 14 ( 2), Article 3, 1-17.

Soliman, F. (2013). "Does Innovation Drive Sustainable Competitive Advantages?, " Journal of Modern Accounting and Auditing, 9(1), 130-143.

Somsuk, N., Laosirihongthong, T. (2014). "A Fuzzy AHP to Prioritize Enabling Factors for Strategic Management of University Business Incubators: Resource-based View". Technological Forecasting and Social Change, 85, 198-210.

Sonnentag, S. (2003). "Recovery, Work Engagement, and Proactive Behavior: A New Look at the Interface Between Nonwork and Work". Journal of Applied Psychology, 88(3), 518-528.

Southiseng, N. and Walsh, J. (2010), "Competition and management issues of SME' entrepreneurs in laos: Evidence from empirical studies in Vientiane municipality", Savannakhet and Luang Prabang. Asian Journal of Business Management, 2(3), 57-72.

Tang, J.; Tang, Z.; Zhang, Y., and Li, Q. (2007). "The Impact of Entrepreneurial Orientation and Ownership Type on Firm Performance in the Emerging Region of China". Journal of Developmental Entrepreneurship 12(4), 383-397.

Thompson, M. and Heron, M. (2006). "Relational Quality and Innovative Performance in R\&D Based Science and Technology Firms". Human Resource Management Journal, 16, 28-47.

TIEC, (2017). "TIEC in numbers", retrieved from http://www.tiec.gov.eg/en-us/about/Pages/TİECinNumbers.aspx Tötterman, H.. Sten, J. (2005). "Start-ups: Business Incubation and Social Capital", International Small Business Journal, 23(5), 487-511.

Ugaddan, R. G.; Oh, H-G and Park, S. M. (2016). "An Exploration of Entrepreneurial Orientation and Organizational Commitment: With a Focus on a Role of Public Service Motivation", Asian Review of Public Administration, 27(1-2), 1-32.

Vantilborgh, T. ; Joly , J. and Pepermans, R. (2015). "Explaining Entrepreneurial Status and Success from Personality: An Individual-Level Application of the Entrepreneurial Orientation Framework". Psychologica Belgica, 55 (1), 32-56.

Verdu, A. J. and Gomez-Gras, J.-M.,(2009). "Measuring the organizational responsiveness through managerial flexibility", Journal of Organizational Change Management, 22 (6), 668-690, Wang, CL. (2008). "Entrepreneurial orientation, learning orientation, and firm performance". Entrepreneurship Theory and Practice, 32(4), 635-657. 
Werf, R. (2016). "3 Key Types of Organizational Commitment", Effectory.

Retrieved from:https://www.effectory.com/knowledge/blog/3-key-types-oforganisational-committment/

World Bank, (2015). "Small and Medium Enterprises (SMEs) Finance". Retrieved from: http://www.worldbank.org/en/topic/financialsector/brief/smesfinance

Xerri, M.J. and Brunetto, Y. (2013), "Fostering innovative behaviour: the importance of employee commitment and organisational citizenship behaviour", The International Journal of Human Resource Management, 24(16), 3163-3177.

Zajac, E.J., Kraatz, M.S. and Bresser, R.K.F. (2000), "Modeling the dynamics of strategic fit: a normative approach to strategic change", Strategic Management Journal, 21 (4), 429-453.

Zannad, $\mathrm{H}$ and Rouet, V. (2003). "Organizational commitment in innovative companies". XII ème Conférence de l'Association Internationale de Management Stratégique Les Côtes de Carthage $-3,4,5$ et 6 juin 2003.

Zhou L., W u W-P, Luo X. (2007). "Internationalization and the performance of born-global SMEs: the mediating role of social networks". Journal of International Business Studies, 38:673-690. 